\title{
LEGALISASI PERNIKAHAN SEJENIS DALAM PERSPEKTIF HUKUM MORAL JOHN CALVIN
}

\author{
Imelda Ginting \\ Sekolah Tinggi Teologi Reformed Injili Internasional
}

\begin{abstract}
First of all, the article "John Calvin's Moral Law Perspective on Legalization of Same-sex Marriage" will briefly explained the fact of LGBT (lesbian, gay, bisexual, transgender), situational ethics as the justifying principle, and the proponent community that looking forward the legalization of same-sex marriage. The author will explain the basis to support the legalization of same-sex marriage. Subsequently, the author will explain from John Calvin's moral law, whether the basis for same-sex marriage are justified or not. In this paper, the author will argue that samesex marriage was not compatible with Calvin's moral law, thus is not accepted in the church.
\end{abstract}

KEYWORDS: same-sex marriage, moral law, John Calvin.

ABSTRAK: Artikel yang berjudul "Legalisasi Pernikahan Sejenis dalam Perspektif Hukum Moral John Calvin" ini pertama-tama akan menjelaskan sekilas mengenai fakta LGBT (lesbian, gay, biseksual, transgender), etika situasi sebagai dasar pembenaran, dan komunitas yang memperjuangkan legalisasi pernikahan sejenis. Pada bagian ini penulis akan memaparkan mengenai dasar yang dipergunakan sebagai pembenaran legalisasi pernikahan sejenis. Setelah itu penulis akan melakukan tinjauan terhadap hukum moral John Calvin untuk menyoroti, apakah dasar yang dijadikan pembenaran pernikahan sejenis itu tepat atau tidak. Temuan dalam tulisan ini, legalisasi pernikahan sejenis tidak memiliki landasan yang sesuai dengan hukum moral Calvin, dan karena itu tidak dapat diterima oleh 
gereja.

KATA KUNCI: pernikahan sejenis, hukum moral, John Calvin.

\section{Pendahuluan}

Penulis setuju bahwa diskriminasi terhadap Lesbi, Gay, Biseksual, Transgender (LGBT) harus diakhiri. Negara harus melindungi siapa pun dia dari kekerasan yang mengancam kemanusiaan seorang individu, termasuk mereka yang berada dalam komunitas LGBT. Harus diakui, bahwa individu, dan komunitas LGBT di banyak negara telah mengalami kekerasan, bahkan mendapat perlakuan yang amat tidak manusiawi. Dan semua orang yang menghargai martabat kemanusiaan, tentu tidak setuju dengan tindakan kekerasan terhadap LGBT.

Perlakuan diskriminatif terhadap LGBT telah membangkitkan komunitas tersebut untuk berjuang mendapatkan pengakuan atas keberadaannya di seluruh penjuru dunia, termasuk Indonesia. Salah satu perjuangan mereka adalah dilegalkannya pernikahan sesama jenis. Pada banyak negara perjuangan kaum LGBT itu berhasil, legalisasi pernikahan sejenis telah diberlakukan di banyak negara. Perjuangan untuk melegalkan pernikahan sejenis juga terjadi di Indonesia, namun hingga saat ini perjuangan tersebut belum membuahkan hasil, karena undang-undang perkawinan di negeri ini hanya mengakui pernikahan heteroseksual.

Upaya melegalisasi pernikahan sejenis ternyata menimbulkan persoalan baru. Di negara-negara yang sudah melegalkan pernikahan sejenis, gereja atau lembaga agama yang tidak bersedia memberkati pernikahan sejenis karena tidak sesuai dengan keyakinan iman mereka anut, dapat dikriminalisasikan. Ketakutan lembaga-lembaga agama terhadap legalisasi pernikahan sejenis juga terjadi di Indonesia. Karena itu di negeri ini individu atau komunitas yang menolak pernikahan sejenis berusaha 
untuk menghambat gerakan-gerakan yang berjuang untuk melegalkan pernikahan sejenis itu, salah satu caranya adalah dengan pelarangan promosi LGBT. Tulisan ini akan memaparkan apa yang menjadi dasar pernikahan sejenis, dan mengapa kelompok agama menolak pernikahan sejenis.

\section{Dasar Perjuangan Pernikahan Sejenis}

"Etika Situasi" atau yang disebut juga dengan istilah moralitas baru ${ }^{1}$ merupakan dasar pembenaran legalisasi pernikahan sejenis. Etika ini menyatakan bahwa diskriminasi, kekerasan yang dialami oleh kaum LGBT harus diakhiri dengan pemberian payung hukum yang menjamin komunitas itu terlindungi. Fletcher, seorang tokoh moralitas baru menyatakan, Yesus sendiri tidak membahas banyak hal terkait homoseksual, kecuali masalah perceraian dan perzinahan. Menurutnya, Yesus juga tidak membahas masalah hidup bersama sebelum menikah. Maka menurut Fletcher, apakah tindakan ini salah atau benar, tergantung pada situasi. Pernyataan Fletcher ini menjadi pembenaran perilaku LGBT, sebagaimana dikatakan Pendeta Stephen Suleeman,"2 "Para nabi di Perjanjian Lama, dan Yesus sendiri hampir-hampir tidak pernah berbicara tentang homoseksualitas sebagai dosa. ${ }^{3}$ Dengan pengertian inilah juga, maka Suleeman mendorong sekolah-sekolah tinggi teologi, gereja-gereja, dan komunitas-komunitas Kristen khususnya, serta komunitas-komunitas

\footnotetext{
1 Etika situasi juga disebut dengan new morality pada tanggal 2 Februari oleh The Supreme Sacred Congregation of the Holy Office. Joseph Fletcher, Situation Ethics The New Morality (London: Westminster John Knox Press, 1966), 34.

2 Pdt. Drs. Stephen Suleeman, M.Th, Th.M., dosen di STT Jakarta, dengan jabatan Kepala Unit Penelitian Lapangan, Kepala Pusat Penelitian dan Pengabdian Masyarakat, Pengampu MK: Teologi dan Komunikasi, Ilmu-ilmu Sosial, CP 1, Praktek Lapangan. Sekolah Tinggi Teologi Jakarta. http://sttjakarta.ac.id/. (diunduh 21 September 2015). 3 Stephen Suleeman, Memahami Homoseksualitas Lewat Alkitab. http://1smart.blogspot.co.id. diunduh 21 September 2015.
} 
agama lainnya, "semakin menggumuli masalah LGBT dengan sungguhsungguh sehingga kita dapat menciptakan sebuah masyarakat yang lebih ramah, lebih terbuka, dan lebih menyembuhkan"..4 Untuk memperjelas pandangannya tersebut, Suleeman memaparkan realitas pernikahan heteroseksual dan homoseksual. Ia menyatakan ada banyak dari pernikahan heteroseksual tidak memberikan kebahagiaan kepada pasangan suami-istri itu. "Coba lihat pernikahan antara Pangeran Charles dengan Lady Diana. Atau pernikahan antara Elizabeth Taylor dengan sekian banyak suaminya (kalau tidak salah ada tujuh orang, penulis). Apakah itu pernikahan yang lebih baik daripada pernikahan LGBT? Saya katakan, Tidak!". ${ }^{5}$

Diskriminasi terhadap LGBT tentu saja harus diakhiri, namun itu tidak berarti harus menerima fakta LGBT itu sebagai kebenaran. Komunitas LGBT juga harus menghormati mereka yang hidup menurut hukum agama yang menolak pernikahan sejenis. Dalam hal ini penulis akan mengadakan tinjauan terhadap hukum moral John Calvin sebagai dasar penolakan atas legalisasi pernikahan sejenis.

\section{Hukum Moral John Calvin}

Menurut Calvin, Tuhan memberikan hukum moral dalam dua loh batu. Bagian yang pertama mengenai ibadah kepada Tuhan. "God instructs us in piety and the proper duties of religion, by which we are to worship his majesty". ${ }^{6}$ Kedua adalah kewajiban untuk mengasihi sesama. "The second table prescribes how in accordance with the fear of his name we ought to

\footnotetext{
4 Stephen Suleeman. Pemahaman tentang Tubuh dan LGBT dalam Teologi Yudeo-Kristen. 14 Januari 2013. www.peruati.com. (diakses 21 September 2015).

5 Stephen Suleeman, Memahami Homoseksualitas Lewat Alkitab

6 Calvin, Institutes, 2.8.1.
} 
conduct ourselves in human society". ${ }^{7}$ Meskipun hukum ini terbagi dua, tetapi seluruh hukum ini berpusat pada Tuhan, dan motivasi orang Kristen menaati hukum menurut Calvin adalah cinta pada Tuhan.

The beginning of obedience, as well as its source, foundation, and root, is (the) love of God... This love can not exist until we have tasted the goodness of our God. For as long as we conceive of God as being opposed to us, of necessity we will flee from him. Therefore do we wish to love him? Do we wish to be reformed by being obedient to him that we might receive all of our pleasure in his service? Then we must realize that he is our Father and Savior, that he only wants to be favorable to us. Thus once we have tasted his mutual love which he receives for us, then we will be motivated to love him as our Father. For if this love is in us, then there will be no doubt that we will obey him and that his law will rule in our thoughts, our affections, and in all our members. ${ }^{8}$

Pada hukum yang pertama, Tuhan menyatakan "Akulah Tuhan Allahmu”. Kata "Tuhan" yang dipakai adalah “Jehovah" menunjukkan kekuasaan dan pemerintahan ada di tangan Tuhan. Segala sesuatu berasal dari Tuhan maka segala sesuatu tunduk pada Tuhan (Roma 11:36). Hanya dengan pengertian ini, manusia dengan sukarela menundukkan diri pada Tuhan. 9 "I am Jehovah your God. God first shows himself to be the one who has the right to command and to whom obedience is due."10

Kalimat berikutnya adalah, "Yang membawa kamu keluar dari Mesir, keluar dari perbudakan". Menurut Calvin bagian ini menegaskan bahwa Tuhan pemilik orang Israel dan Tuhan mencintai orang Israel. Pengertian ini akan membuat bangsa Israel makin terdorong untuk mempersembahkan

\footnotetext{
7 Calvin, Institutes, 2.8.11.

8 John Calvin, "John Calvin's Sermons on the Ten Commandments", ed. and trans. Benjamin W. Farley (Grand Rapids: Baker, 1980), 45 dalam Jones, The Law And The Spirit Of Christ. Theological Guide to Calvin's Institutes Essay and Analysis, 319.

9 Calvin, Institutes, 2.8.13.

10 Calvin, Institutes, 2.8.14. Ayat Alkitab yang dikutip Calvin untuk mendukung pergertian di atas adalah Yeremia 31:33, Matius 22:32 dan Maleaki 1: 6.
} 
dirinya kepada Tuhan dan menaati perintah Tuhan karena mereka mencintai dan hormat pada Tuhan. ${ }^{11}$

Selanjutnya dikatakan, "Jangan ada padamu allah lain di hadapan$\mathrm{Ku}^{\prime \prime}$. Bagian ini menunjukkan bahwa umat Tuhan hidup di hadapan Allah atau dengan kata lain, Tuhan mengawasi hidup umat-Nya. Tuhan mengawasi berarti Tuhan menuntut ketaatan. Tetapi bagian ini juga mengandung janji:

Before my face, makes the offense more heinous because God is provoked to jealousy as often as we substitute our own inventions in place of him...therefore when God by his present power and grace testified that he kept watch over the people whom he had chosen, he warned them to keep them even more from the crime of rebellion, that they could introduce no new gods without his witnessing and observing their sacrilege. ${ }^{12}$

Tuhan sudah membebaskan umat-Nya dari belenggu kesengsaraan, oleh karena itu umat dengan taat dan rela, menyembah dan memuliakan Tuhan yang sudah memberikan kemerdekaan kepada mereka. Supaya manusia bisa tetap memuliakan Tuhan, bukan ilah lain, maka Tuhan memperkenalkan siapa diri-Nya supaya umat bisa membedakan diri-Nya dari ilah palsu.

Calvin menyatakan bahwa tidak ada diskriminasi, karena semua manusia diikat oleh satu ikatan yaitu sama-sama manusia. Dalam kalimat yang lebih jelas "kasihilah setiap orang sebagaimana mereka adanya". Asal mereka manusia maka mereka sesama. Semua manusia adalah sesama karena Tuhan menciptakan manusia untuk saling membantu satu dengan yang lain. Tetapi karena manusia berdosa sudah dibutakan oleh kesombongannya dan fokus pada diri sendiri, maka mereka membedabedakan sesama dan mengabaikan kewajiban mengasihi mereka. Relasi

\footnotetext{
11 Jones, 319.

12 Calvin, Institutes, 2.8.16.
} 
yang mereka bangun adalah relasi yang saling menguntungkan. ${ }^{13}$

Kasih tidak dibatasi kedekatan relasi. Calvin tidak memungkiri bahwa semakin dekat relasi semakin besar kewajiban untuk mengasihi. Ini hal yang wajar makin dekat relasi makin peduli dan makin sadar untuk memberikan kasih kepada mereka. Hal ini tidak bertentangan dengan kehendak Tuhan. ${ }^{14}$ Tetapi yang menjadi penekanan Calvin adalah:

The word neighbor includes even the most remote person: we ought to embrace the whole human race without exception in a single feeling of love, here there is no distinction between barbarian and Greek, worthy and unworthy, friends and enemy, since all shoud be contemplated in God, not in themselves. ${ }^{15}$ Therefore, if we rightly direct our love, we must first turn our eyes not to man, the sight of whom would more often engender hate and love, but to God, who bids us extend to all men the love we bear to him, that this may be an unchanging principles: whatever the character of man, we must yet love him because we love God. ${ }^{16}$

Sejauh apa manusia mencintai sesama. Di dalam Imamat 19:18, Tuhan menyatakan "seperti mencintai diri sendiri". Ada dua pengertian yang Calvin tekankan dalam bagian ini. Pertama, mengasihi sesama seperti mengasihi diri sendiri bukan dalam pengertian "manusia mencintai sesama sebagaimana mereka mencintai diri mereka sendiri yang berdosa tetapi mengasihi sesama sebagai pribadi, sebagaimana diri sendiri adalah seorang pribadi". ${ }^{17}$ Kedua, karena kasih ini begitu nyata dan kuat dalam hidup manusia, maka mereka bisa mengerti dengan jelas sehingga dengan tekun mengaplikasikan kasih ini pada sesama. Tetapi pengertian ini bukan menyatakan bahwa cinta diri yang pertama dan kasih pada sesama berada

13 Calvin, Commentary on a Harmony of the Evangelists. Matthew, Mark, and Luke. trans. rev William Pringle. vol. 3, (Grand Rapids: Baker Book Company. 1993), 61.

14 Calvin, Institutes, 2.8.55.

15 William Klempa, "John Calvin on Natural Law", dalam John Calvin $\mathcal{E}$ The Church, ed. Timothy George, (Kentucky: John Knox Press. 1990), 87.

16 Calvin, Institutes, 2.8.55.

17 Jones, 313. 
di posisi kedua. Tetapi kasih pada diri sendiri yang dimiliki manusia, ditransfer kepada sesama. Sebagaimana yang dikatakan oleh Rasul Paulus, dalam 1 Korintus13: 5, kasih tidak mencari keuntungan diri: ${ }^{18}$

The Lord has not establish a rule regarding love of ourselves to which charity toward others should be subordinate. But he shows that the emotion of love, which out of natural depravity commonly resides within ourselves, must now be extended to another, that we may be ready to benefit our neighbor with no less eagerness, ardor and care than ourselves. ${ }^{19}$ Hence it is very clear that we keep the commandments not by loving ourselves but by loving God and neighbor; that he life the best and holiest life who lives and strives for himself as little as he can, and that no one lives in a worse or more evil manner than he who lives and stives for himselves alone, and thinks about and seeks only his own advantage. ${ }^{20}$

Calvin menyatakan kesempurnaan kekudusan umat Tuhan disimpulkan dengan mengasihi Tuhan (Ulangan 6:5, 11:13) dan sesama manusia (Imamat 19:18, Matius 22:37, 39). ${ }^{21}$

Christ says that all the Law and the Prophets depend on these two commandments; not that he intends to limit to this summary all the doctrine of scripture, but because all that is anywhere taught as to a manner of living a holy and righteous life must be referred to these two leading points. ${ }^{22}$

Di dalam tafsirannya, Calvin menyatakan bahwa Rasul Paulus juga menekankan pengajaran Yesus ini pada surat yang ditulisnya.

There is no true love where there is not fear of God and uprightness of conscience.The sum of the law is this, that we may worship God with true faith and pure conscience, and that we may love one another. ${ }^{23}$ Now, since

\footnotetext{
18 Calvin, Institutes, 2.8.55.

19 Calvin, Institutes, 2.8.55.

20 Calvin, Institutes, 2.8.53.

21 Calvin, Institutes, 2.8.51.

22 Calvin, Commentary on a harmony of the evangelists. Matthew, Mark, and Luke, 58.

23 Calvin, Commentaries of The Epistle of Paul to the Galatians And Ephesians, terj. rev. William Pringle, Reprint 1993 (Baker Book House Company, 1993), 27.
} 
salvation of men rests of faith, and since the perfect worship of God rest on faith, and a good conscience and love, we need no wonder if Paul makes sum of the law to consists of them. ${ }^{24}$

Dari pengajaran Rasul Paulus di atas, penekanan keselamatan bukan pada kasih tetapi pada iman. Dan dengan iman dan hati nurani yang murni, manusia bisa mengasihi sesama manusia. Dengan iman, hati nurani yang murni dan kasih, maka hidup kudus dan benar terealisasi. Agar hal ini terealisasi pertama-tama hati manusia dipenuhi dengan cinta Allah, dan dari kepenuhan akan cinta Tuhan inilah akan mengalir cinta kepada sesama. Inilah yang dijelaskan Rasul Paulus dalam 1 Timotius 1: 5 tujuan dari perintah adalah kasih yang berasal dari hati nurani serta iman yang murni. . $^{\prime \prime}$ In the other words, here is true piety, from which love is derived". ${ }^{26}$

Calvin menyatakan seringkali kasih pada sesama ditekankan seolaholah kasih pada Tuhan dan sesama dapat dirangkumkan menjadi kasih pada sesama saja karena kasih Tuhan yang ada pada diri umat-Nya akan terpancar dalam kehidupan bersama.

The purpose of the whole law: the fulfillment of righteousness to form human life to the archetype of divine purity. For God has so depicted his character in the law that if any man carries out in deeds whatever is enjoined there, he will express the image of God, as it were, in his own life. ${ }^{27}$

Penjelasan mengenai "mengasihi Tuhan dan sesama" dicatat dalam Matius, Markus dan Lukas. Dalam Matius dan Markus dipaparkan konteksnya, ini adalah pertanyaan terakhir yang disampaikan kepada Yesus oleh ahli Taurat untuk mencobai Yesus, mencari kesalahan Yesus. Yesus

\footnotetext{
24 Calvin, Commentaries of the Epistle of Paul to the Galatians and Ephesians, 28.

25 Calvin, Institutes, 2.8.51.

26 Calvin, Institutes, 2.8.15.

27 Calvin, Institutes, 2.8.51.
} 
menjelaskan pada orang yang berbeda, dan respon yang dihasilkan juga berbeda. Hal ini menunjukkan bahwa Yesus berkali-kali dicobai terkait dengan kebenaran yang sejati, ketaatan pada hukum dan hukum yang mengatur kehidupan. Mereka menanyakan pertanyaan ini meskipun sebenarnya mereka tidak antusias untuk melakukan atau dengan kata lain diubahkan oleh hukum karena mereka kehilangan keagungan dari hukum itu sendiri. Maka mereka bertanya pada Yesus, mengharapkan Yesus akan mengajarkan sesuatu yang lebih sempurna dari hukum moral. Pada Injil Lukas, ahli Taurat bertanya: "Apa yang mesti saya lakukan untuk mendapatkan hidup yang kekal?“ Sedangkan pada Injil Matius dan Markus mereka bertanya: "Apa perintah yang paling tinggi?" Meski pertanyaannya berbeda tetapi tujuannya sama. ${ }^{28}$

Maka sesuai dengan pertanyaan mereka, bagaimana mendapatkan hidup kekal atau bagaimana menjadi benar di hadapan Tuhan, maka Yesus menjawab: "Kasihilah Tuhanmu dengan segenap hatimu, jiwamu dan segenap kekuatanmu, dan kasihilah sesamamu manusia seperti dirimu sendiri". Pada peristiwa ini Yesus menempatkan diri-Nya sebagai hakim. Tetapi tidak seorang pun yang dapat dibenarkan oleh hukum di hadapan Tuhan, meskipun hukum itu sendiri benar adanya. ${ }^{29}$

Jawaban Yesus pada Injil Markus, Yesus menyatakan bahwa "Jehovah alone is the God of Israel", pernyataan ini mendukung otoritas hukum. Pertama, manusia yang mengerti bahwa Tuhan yang disembah adalah Pencipta langit dan bumi, mereka akan menjadi antusias menyembah Tuhan. Kedua, Tuhan mengadopsi mereka menjadi anak-anak Tuhan, ini menjadi dorongan untuk mencintai Tuhan dan berbalik dari ketidakpercayaan mereka. ${ }^{30}$

\footnotetext{
28 Calvin, Commentary on a Harmony of the Evangelists. Matthew, Mark, and Luke, 58.

29 Ibid., 58.

$30 \quad$ Ibid., 58 .
} 
Tuhan memberikan hukum dalam dua loh batu, yang pertama menekankan ibadah kepada Tuhan dan yang kedua mengenai kasih pada sesama. Mengapa yang ditekankan perintah pertama dulu? Karena hanya yang mencintai Tuhan yang menaati perintah Tuhan.

Let us therefore learn, that the commencement of godliness is the love of God, because God disdains the forced service of men, and chooses to be worshipped freely and willingly; and let us also learn, that under the love of God is included the reverence due to him. ${ }^{31}$

Umat Tuhan bisa mencintai Tuhan karena cinta Tuhan sudah memenuhi hati mereka. Dan dari perintah Tuhan agar manusia mengasihi Tuhan dengan segenap hati, jiwa dan kekuatan, ini menyatakan tidak ada bagian dalam diri umat Tuhan yang tidak dipenuhi olah kasih Tuhan. Respon terhadap kasih Tuhan ini maka umat Tuhan akan mengasihi Tuhan dengan segenap hati, jiwa dan kekuatan, bahwa tidak ada bagian dalam diri manusia yang tidak didedikasikan kepada Tuhan. Ringkasan dari perintah ini tidak menunjukkan apa yang bisa manusia lakukan tetapi apa yang seharusnya manusia lakukan. ${ }^{32}$

In the commandments of the Law, God does not look at what men can do, but at what they ought to do; since in this infirmity of the flesh it is impossible that perfect love can obtain dominion, for we know how strongly all the senses of our soul are disposed to vanity. Lastly, we learn from this, that God does not rest satisfied with the outward appearance of works, but chiefly demands the inward feelings, that from a good root good fruits may grow. ${ }^{33}$

Hukum yang kedua, sama dengan hukum yang pertama, ini menekankan bahwa hukum yang kedua tergantung pada hukum yang pertama. Manusia hanya bisa mengasihi sesama hanya jika mereka

\footnotetext{
$31 \quad$ Ibid., 58.

32 Calvin, Commentary on a Harmony of the Evangelists .Matthew, Mark, and Luke, 59.

33 Calvin, Commentary on a Harmony of the Evangelists. Matthew, Mark, and Luke,59.
} 
mengasihi Tuhan. Jika manusia belum mengasihi Tuhan maka kasih yang mereka nyatakan pada sesama, bukan kasih sebagaimana yang Tuhan kehendaki.

The commandment to love neighbours, he tells us, is like the first, because it depends upon it. For, since every man is devoted to himself, there will never be true charity towards neighbours, unless where the love is God reigns; for it is a mercenary love, which the children of the world entertain each other, because every one of them has regard to his own advantage. On the other hand, it is impossible for the love of God to reign without producing brotherly kindness among men. ${ }^{34}$

Pada saat Musa memerintahkan manusia untuk mengasihi sesama, ini tidak berarti manusia harus mencintai diri terlebih dahulu, atau cinta diri pada posisi pertama dan kemudian mengasihi sesama. Tetapi Musa mengajarkan bahwa sesama dan diri sendiri berada pada posisi yang sama.

But as we are too much devoted to ourselves, ... places our neighbours in a equal rank with us; thus forbidding every man to pay so much attention to himself as to regard others, because kindness unites all in one body. And by correcting the self love which separates some persons from others, he brings each of them into a communion union, and as it were into a mutual embrace. ${ }^{35}$

Selanjutnya, penjelasan Yesus pada Injil Lukas 10: 28, Tuhan berkata "Lakukan ini maka kamu akan dibenarkan”. Tuhan membenarkan manusia bukan karena hukum tidak mengajarkan kebenaran yang sempurna tetapi karena manusia gagal melakukannya. Maka Rasul Paulus menyatakan adalah tidak mungkin manusia mendapatkan hidup melalui hukum karena daging lemah (Roma 8:3). Hukum mengajarkan bagaimana manusia mendapatkan hidup yang kekal dengan perbuatan, tetapi tidak ada seorang manusia pun yang mendapatkan hidup yang kekal, ini bukan karena 
kesalahan hukum atau doktrin ${ }^{36}$ tetapi karena kesalahan manusia itu sendiri. Inilah penekanan ajaran Yesus kepada orang-orang yang melawan ajaran Yesus. $^{37}$

Tuhan menekankan bahwa apa yang dituntut dari hukum dan ajaran para nabi adalah mengasihi Tuhan dan sesama manusia; maka seolah-olah ia mengatakan bahwa seluruh hukum dan ajaran Rasul terangkum dalam mengasihi Tuhan dan sesama. Dan mengartikan salah pengajaran Rasul Paulus dari Roma 13:8 kasih kegenapan hukum Taurat karena kesalahan pengertian ini maka ada yang salah mengajarkan bahwa tidak ada yang lebih tinggi dari ajaran nabi dan hukum, kecuali kasih pada sesama. ${ }^{38}$

For as a distinction ought to be made between the promises and the commandments, so in this passage Christ does not state generally what ought to learn from the word of God, but explains, in a manner suited to the occasion, the end to which all the commandments are directed. Yet the free forgiveness of sins, by which we are reconcile to God, confidence is calling on God, which is the earnest of the future inheritance, and all the parts of faith, though they hold the first rank in the Law, do not depend on these two commandments, fot it is one thing to demand what we owe, and another things to offer what we do no possess. ${ }^{39}$

Respon ahli Taurat pada Markus 12:32 berbeda dari yang di Matius, ia dengan rendah hati menyatakan kesetujuannya bahwa Yesus mengajarkan

\footnotetext{
36 Hukum yang Tuhan berikan sempurna tetapi manusia tidak dapat menempatkan kesempurnaan dari hukum. Berikut penjelasan Calvin: Indeed, we do not deny that the law of God contains perfect righteousness. Luk 17:18 Yet because the Lord deigns to accord to it the honor of righteousness, we do not take away what he has given. We therefore willingly confess that perfect obedience to the law is righteousness, and that the keeping of each commandment is a part of righteousness; provided that in the remaining parts the whole sum of righteousness is contained. But we deny that such a form of righteousness is contained. But we deny that such a form of righteousness exists anywhere. And we cast off law righteousness, not because it is defective and mutilated of itself, but because, due to the weakness of our flesh, it is nowhere visible. Calvin, Institutes, 3.7.7.

37 Calvin, Commentary on a Harmony of the Evangelists. Matthew, Mark, and Luke, 60.

38 Calvin, Commentary on a Harmony of the Evangelists. Matthew, Mark, and Luke, 64.

39 Ibid., 64.
} 
kebenaran. Meskipun ia pernah terkontaminasi dengan ajaran yang salah, ia sudah mendapatkan benih Firman yang sejati, maka ia bisa meninggalkan ajaran yang salah dan dari kebiasaan yang salah. ${ }^{40}$

From this reply it may also be concluded, that Christ did not precisely include under these two words the rule of life, but embraced the opportunity which presented itself for reproving the false and hypocritical holiness of the sribes, who, giving their whole attention to outward ceremony, almost enterily disregarded the spiritual worship of God, and cared little aboutbrotherly kindness. ${ }^{41}$

Bagian ini ditutup dengan pernyataan bahwa tidak ada seorang pun yang berani bertanya pada Yesus. Calvin menggambarkan mereka seperti binatang buas liar yang tidak berani membuka mulut di hutan. Yesus memberikan pengajaran yang menunjukkan kesalahan mereka dan kebenaran ditegakkan. Dari bagian ini, Calvin mendorong umat Tuhan, untuk terus menyuarakan kebenaran karena kebenaran pasti menang. ${ }^{42}$

\section{Penolakan Legalisasi Pernikahan Sejenis dalam Perspektif Hukum Moral Calvin}

\section{LGBT Menafikan Kejatuhan Manusia dalam Dosa}

Tuhan memberikan pengertian keadilan dan kebenaran kepada manusia, karena manusia adalah gambar dan rupa Tuhan. Pengertian ini tentu saja, pengertian yang sempurna untuk ciptaan. Namun setelah kejatuhan manusia, pengertian ini menjadi rusak total. Tanpa intervensi dan anugerah dari Tuhan, manusia tidak lagi memahami kebenaran dan keadilan yang sejati. ${ }^{43}$

\footnotetext{
$40 \quad$ Ibid., 64.

41 Commentary on a Harmony of the Evangelists, Matthew, Mark, and Luke, 64.

42 Ibid., 65.

43 Calvin, Commentary upon The Book Of Psalms, 319.
} 
Maka Tuhan memberikan hukum-hukum-Nya, salah satunya hukum moral agar manusia mengerti kebenaran yang sejati. Calvin menyatakan bahwa hukum Tuhan juga memberikan bijaksana yang sejati pada manusia.

God has taught in his law full and perfect righteousness and truth. It was God's design to exhibit in the law a perfect rule of righteousness. The doctrine of the law is honoured with these encomiums, that all of us may learn to derive wisdom from it, and that no man may devise for himself any other standard of rectitude or righteousness than that which is exhibited in law; a very necessary lesson, since every man would willingly frame for himself a new pattern or standard of righteousness. ${ }^{44}$

Dari hukum moral, manusia mengetahui standar kebenaran Tuhan, standar hidup yang Tuhan kehendaki dari manusia. Setelah manusia jatuh dalam dosa, manusia jauh dari standar kebenaran Tuhan, dan manusia tidak hidup sesuai dengan standar Tuhan. Hukum moral seperti cermin kepada semua manusia, baik yang dipilih maupun yang tidak dipilih. ${ }^{5}$ Hukum moral menunjukkan kelemahan manusia, memperjelas pelanggaran serta ketidaklayakan manusia. ${ }^{46}$

LGBT adalah tindakan yang menyeleweng dari kehendak Tuhan. Maka gereja harus dengan tegas menyatakan bahwa tindakan ini adalah dosa. Sikap ini untuk menyadarkan dan mendorong mereka agar meninggalkan dosanya. Hukum moral Calvin memberikan kabar sukacita bagi kaum LGBT. Menyadari diri sebagai manusia berdosa justru sebagai titik awal kesadaran bahwa manusia memerlukan Juruselamat dan bertobat.

"They come to realize that they stand and are upheald by God's hand alone; naked and empty handed, they flee to his mercy, repose enterily in it,

44 Ibid., 18-19.

45 Calvin, Institutes, 2.7.9.

46 Calvin, Commentary Upon The Acts of The Apostles. 133 
hide deep within it and seize upon it alone for righteousness and merit". ${ }^{47}$ Daniel R. Heimbach menambahkan, "Anyone (again, without exception) who has ever violated God's prohibition of homosexual sex can, we are told, repent, forsake their sin, be forgiven, and totally cleansed". ${ }^{48}$

Dan hati yang sudah dipulihkan ini akan memberikan semangat dan kekuatan untuk tubuh untuk menghidupi hukum Tuhan. Pengertian jiwa yang dipulihkan dalam hal ini adalah jiwa yang menyadari siapa dirinya di hadapan Tuhan, jiwa yang hancur karena dosa-dosanya. ${ }^{49}$ Jiwa yang senantiasa berharap pada Tuhan dan dengan rendah hati memohon pertolongan dari Tuhan untuk melakukan hukum Tuhan.

\section{Pernikahan Sejenis Salah Menurut Alkitab}

Calvin menasihatkan, meskipun manusia sudah diselamatkan, sudah lahir baru, kecondongan hati manusia adalah melakukan dosa. Bahkan mungkin saja, ada saatnya mereka jauh dari Tuhan dan terjerumus dalam dosa LGBT. Namun mereka tidak mencintai dosa lagi, mereka membenci dosa dan bahkan menyedihkan hati mereka. Maka orang kudus dengan berani dan rendah hati memohon pertolongan dari Tuhan, didasarkan pada janji Tuhan sendiri bahwa Roh Kudus akan senantiasa memberikan pertolongan ${ }^{50}$. Setuju dengan Calvin, Stanley J. Grenz menyatakan bahwa Roh Kudus akan menolong umat-Nya untuk hidup dalam kehidupan seks yang kudus.

47 Calvin, Institutes, 2.7.8.

48 Daniel R. Heimbach, True Sexual Morality: Recovering Biblicak Standards for a Culture in Crisis, (Illinois: Cossway Books, 2004), 187.

49 Calvin, Commentary Upon The Book Of Psalms, 319.

50 Calvin, Institutes, 2.5.15. 
For Christians of either sexual orientation, the call to live out one's sexuality in ways that bring honor to God is a difficult challenge, especially in the midst of out permissive society. Yet, the resources of the Holy Spirit are greater than the difficulty of the calling, and obedience to the divine design is path to greatest joy. ${ }^{51}$

Tuhan adalah pemilik dunia ini, dan Tuhan yang memegang pemerintahan-Nya. Maka Tuhan memberikan hukum moral sebagai tatanan hidup yang dikehendaki Tuhan, sehingga manusia bisa membedakan yang baik dan yang jahat. Bentuk ketaatan manusia menunjukkan siapa yang menjadi tuannya. Jika Tuhan yang menjadi tuannya maka manusia akan taat pada Tuhan. Tetapi jika dosa yang menjadi tuannya maka ia akan taat pada dosa. ${ }^{52}$ Dan barangsiapa tidak taat pada Tuhan, ia akan mendapatkan hukuman. ${ }^{53}$

Tetapi kesukaan manusia berdosa adalah hal-hal yang merusak, dan terkutuk. ${ }^{44}$ Bijaksana kedagingan manusia berdosa berlawanan dengan bijaksana Tuhan. 55 "All men naturally aspire after happiness, but instead of searching for it in the right path, they designedly prefer wandering up and down through endless by paths, to their ruin and destruction". ${ }^{56}$

Jika dibiarkan, maka manusia berdosa akan seperti kuda yang lepas di padang. Untuk menjaga keteraturan hidup, Tuhan menempatkan hukumNya di hati manusia, dan seluruh tindakan manusia didasarkan pada hukum Tuhan ini. Dengan demikian hidup manusia bukan berdasarkan apa yang mereka anggap baik atau tidak, tetapi terikat pada ketetapan Tuhan.

\footnotetext{
51 Stanley J. Grenz. Sexual Ethics an Evangelical Perspective. Kentucky: Westminster John Knox Press, 1990. 246.

52 Calvin, Commentaries on the Epistle to Romans, 237.

53 Ibid., 234.

54 Calvin, Commentary upon The Book of Psalm, 32.

55 Calvin, Commentaries on the epistle to Romans, 234.

56 Calvin, Commentary upon The Book of Psalms, 403.
} 
Inilah fungsi kedua dari hukum moral, menjaga komunitas dari kejahatan manusia. Manusia takut pada hukuman yang akan diterima karena melanggar hukum. ${ }^{57}$ Mereka tidak melanggar hukum karena malu, karena sebatas takut pada hukum, bukan pada Tuhan. Fungsi kedua ini terutama untuk yang belum atau tidak lahir baru. Tetapi fungsi kedua ini juga berlaku untuk umat Tuhan yang sudah lahir baru tetapi mereka sedang jauh dari Tuhan. "Event for the children of God, before they are called and while they are destitute of the Spirit of sanctification, so long as they play the wanton in the folly of the flesh, it is profitable for them to undergo this tutelage" ${ }^{58}$

Terkait dengan pernikahan, Calvin menyatakan, meski natur manusia sudah rusak setelah jatuh dalam dosa, tetapi sebenarnya manusia berdosa masih mengetahui pernikahan yang baik, karena Tuhan menanamkan dalam hati mereka. "Even the pagans, therefore, have always recognized the natural duties of sexual restraint, heterosexual monogamy, marital fidelity, procreation of children, bondage to kin, and the like, which are essectial to sexual morality and the survival of marriage and the family". ${ }^{59}$

Tetapi manusia berdosa tetap mengeraskan hati. Tanpa hukum, maka kehidupan binatang buas di hutan lebih teratur daripada hidup manusia. Tanpa hukum yang membatasi, maka kerusakan akibat kejahatan manusia lebih mengerikan daripada kerusakan yang diakibatkan binatang buas. Maka hukum sangat penting untuk mengatur tatanan hidup manusia berdosa. ${ }^{60}$

Hukum terbaik yang mengatur hidup manusia adalah hukum yang berasal dari Tuhan, yaitu hukum moral. Hukum moral menyatakan kehendak Tuhan dan standar hidup yang Tuhan kehendaki dari manusia.

\footnotetext{
57 Calvin, Institutes, 2.7.10.

58 Calvin, Institutes, 2.7.10.

59 Institutes II.8.6-10 dalam Witte, 78.

60 Calvin, Commentaries on the Book of the Prophet Jeremiah and The Lamentations, 249-250.
} 
Hukum moral menyatakan apa yang baik, yang seharusnya dilakukan manusia. Jika sebuah tindakan menyenangkan Tuhan, maka kebalikan dari tindakan ini, adalah tindakan yang tidak menyenangkan Tuhan. Bahkan dari setiap hukum mengandung larangan dan perintah. Ada tindakan aktif yang dilakukan umat Tuhan dan ada juga tindakan yang harus dijauhi umat Tuhan. ${ }^{61}$ Dengan demikian, semakin hukum moral diaplikasikan dan direalisasikan di dalam kehidupan keseharian, maka semakin baik pula hidup manusia.

Tuhan menganugerahkan hukum moral kepada gereja sehingga gereja mengetahui apa yang baik dan yang jahat. Maka tugas gerejalah untuk menyatakan kebenaran dan mempengaruhi dunia agar dunia tidak semakin rusak dan hancur. Gereja tidak boleh terlena dengan tipuan iblis. Si jahat berusaha keras dan membujuk umat Tuhan dengan halus agar umat Tuhan menyimpang dari kehendak Tuhan. Sebagaimana iblis membujuk Hawa agar memakan buah terlarang. Dalam hal legalisasi pernikahan sejenis, iblis juga menipu gereja dengan cara yang halus. Pertama, mereka meminta keberadaan mereka ditoleransi, kemudian mereka meminta keberadaan mereka dilegalisasi. Kedua, mereka membujuk gereja untuk menerima keberadaan mereka atas dasar kasih dan mendukung terciptanya hidup bersama yang damai.

Calvin menegaskan bahwa cinta kepada Tuhan mendasari cinta kepada sesama. Meskipun Tuhan memerintahkan umat-Nya untuk mengasihi sesama manusia, tetapi hanya kasih yang dilandasi pada cinta pada Tuhan adalah kasih yang baik dan berkenan pada Tuhan. "There is no true love where there is not fear of God and uprightness of conscience. The sum of the law is this, that we may worship God with true faith and pure

61 Calvin, Institutes, 2.8.8. 
conscience, and that we may love one another".62 Justru dengan menyatakan apa yang salah di mata Tuhan kepada manusia berdosa dan menolak legalisasi pernikahan sejenis adalah bukti kasih yang sesungguhnya kepada sesama karena tatanan hidup yang baik tetap terpelihara.

Berdasarkan pemaparan di atas maka landasan penolakan legalisasi pernikahan sejenis dapat dirangkumkan menjadi tiga hal. Pertama, untuk menjaga komunitas dari kejahatan manusia yaitu merusak rancangan pernikahan yang Tuhan tetapkan. Kedua, untuk memelihara tatanan hidup yaitu kehidupan pernikahan seperti yang dikehendaki Tuhan. Ketiga, selama pernikahan sejenis belum dilegalkan maka masih ada rasa malu dan takut pada hukum, maka pernikahan sejenis masih dapat dihindarkan terutama di negara yang belum melegalkan pernikahan sejenis.

\section{Pernikahan Heteroseksual yang Dirancang oleh Tuhan, adalah Pernikahan yang Terbaik}

Keselamatan hanyalah anugerah Tuhan, tidak ada jasa manusia. Selanjutnya menaati perintah Tuhan adalah bagian dari pendidikan untuk manusia yang sudah Tuhan selamatkan.63 Di dalam Ulangan 30: 6 Tuhan menyatakan bahwa Ia akan menyunat hati umat-Nya, dan dalam Yeremia 31:31-32 Tuhan akan menuliskan hukum-Nya di dalam hati umat-Nya. Menurut Calvin ini adalah anugerah rekonsiliasi manusia dengan Tuhan bahwa Tuhan menganugerahkan Roh Kudus untuk regenerasi umat-Nya. Tuhan melahirbarukan hati umat-Nya, membersihkan hati mereka dari kedagingan dunia ini, dan memuliakan Tuhan dengan hati yang suci. ${ }^{64}$

\footnotetext{
62 Calvin, Commentaries of The Epistle of Paul to the Galatians and Ephesians, 27.

63 Calvin, Commentaries on the First Book of Moses Called Genesis, 483.

64 Calvin, Commentaries on the Last Four Books of Moses Arranged in the Form of Harmon, 285.
} 
Pertobatan dari dalam hati, juga nyata pada perbuatan luar. Berikut penjelasan Calvin mengenai pertobatan yang sejati:

Repentance is nothing else but a reformation of the whole life according to the law of God. For God has explained his will in his law; and as much as we depart or deviate from it, so much we depart from the Lord. But, when we turn to God, the true proof is, when we amend our life according to his law, and begin with worshipping him spiritually, the main part of which worship is faith, from which proceeds prayer; and when, in addition to this, we act kindly and justly towards our neighbors, and abstain from all injuries, frauds, robberies, and all kinds of wickedness. This is the true evidence of repentance..$^{65}$

Umat Tuhan tidak hanya mengerti bahwa pernikahan sejenis adalah dosa tetapi dengan aktif menghidupi hidup sebagaimana yang Tuhan kehendaki. Marva J. Dawn mengungkapkan, dalam realitas pelayanannya, kaum homoseksual mengakui bahwa homoseksual adalah dosa. Mereka sudah berdoa meminta pertolongan Tuhan tetapi tetap saja tergoda dengan dosa yang sama. Dawn menanggapinya dengan menyatakan, pilihan ada di tangan mereka apakah mau taat pada kehendak Tuhan atau keraskan hati tetap memberontak. ${ }^{66}$ Hal ini sesuai dengan penjelasan Calvin, bahwa setelah bertobat Roh Kudus memang mengekang kehendak manusia yang berdosa dan mendorongnya untuk menaati kehendak Tuhan. Tetapi Roh Kudus tidak meniadakan kehendak manusia. ${ }^{67}$

Calvin mengingatkan, musuh manusia dalam menjalankan kehendak Tuhan, tidak hanya berasal dari dalam sendiri tetapi juga dari luar diri manusia. Tetapi bukan berarti manusia menyerah kalah dan hanyut dalam

\footnotetext{
65 Calvin, Commentaries on the Twelve Minor Prophets. Commentaries on Hosea, 432.

66 Marva J. Dawn, Sexual Character Beyond Technique to Intimacy (Michigan: William B. Eerdmans Publishing Company, 2001), 109.

67 Calvin, Institutes, 2.5.15 dan Augustine, Sermon clvi.11.11 (MPL 38.855 f.;tr LF Sermons II.769). This is the passage referred to in the last sentence of this section. See also On Rebuke and Grace ii.4 (MPL 44.918; tr NPNF V.473) dalam Calvin, Institutes, 2.5.15.
} 
dosa. Umat Tuhan harus sadar siapa mereka dan bagaimana mereka berespon terhadap diri dan terhadap si jahat. Manusia hanya dapat bersandar pada anugerah Tuhan dan berada dalam posisi siap diajar. Calvin menggambarkan bagaimana umat Tuhan belajar mengerti kehendak Tuhan seperti seorang pelayan yang sepenuh hati memberikan dirinya kepada tuannya. Pelayan harus memperhatikan tuannya dengan seksama supaya bisa mengakomodasi dirinya untuk tuannya. Setiap umat Tuhan tidak bisa lari dari keperluan ini. Tidak ada manusia yang sudah memiliki bijaksana yang cukup untuk memenuhi tuntutan Tuhan. Maka bimbingan yang segar dari Firman Tuhan setiap harinya, memberikan kemajuan dalam diri umat Tuhan untuk mengerti kehendak Tuhan. Dan dengan merenungkan kehendak Tuhan ini setiap harinya, akan meningkatkan ketaatan, memberikan kekuatan untuk melakukan dan terhindar dari pelanggaran. "The law is to the flesh like a whip to an idle balky ass, to arouse it to work. Even for a spiritual man not yet free of the weight of the flesh the law remains a constant sting that will not let him stand still". ${ }^{68}$

Inilah fungsi hukum moral yang terutama untuk umat Tuhan. Tuhan menempatkan hukum moral dalam hati umat-Nya, dan Roh Kudus bertakhta dalam hati umat-Nya. Hukum Tuhan sebagai terang yang memimpin dan membimbing hidup keseharian umat Tuhan. Roh Kudus akan senantiasa menolong mereka untuk mengerti dan melakukan perintah Tuhan. Tuhan membebaskan manusia dari belenggu dosa dan melahirbarukan agar manusia dapat mempersembahkan buah-buah yang kudus dikehendaki Allah Bapa. ${ }^{69}$ Buah-buah ini, hanya dapat dihasilkan oleh orang-orang yang hidup bergantung pada Tuhan, ${ }^{70}$ dan mengikuti

\footnotetext{
68 Calvin, Institutes, 2.7.12.

69 Calvin, Institutes, 2.7.12.

70 Calvin, Commentary upon The Book of Psalms, 169.
} 
pedoman hidup yang Tuhan berikan. ${ }^{71}$

Lahir baru akan menghasilkan hidup yang baru. "The faithful are never reconciled to God without the gift of regeneration, that we may afterwards serve God in holiness of life".72 Tetapi pada saat Tuhan mengajarkan umat-Nya untuk menaati hukum moral, Tuhan juga mengingatkan mereka agar senatiasa mengingat dua anugerah yang sudah Tuhan berikan kepada mereka. Bahwa Roh Kudus yang melahirbarukan mereka adalah Roh Kudus yang akan mendorong mereka untuk mencintai dan menaati kebenaran, mengingatkan dosa mereka sudah diampuni dan sudah diperdamaikan dengan Tuhan. Kesadaran bahwa manusia dibenarkan hanya dengan iman akan mendorong mereka untuk makin mencintai Tuhan dan perintah-Nya. ${ }^{73}$

Tujuan Tuhan memberikan perintah-Nya bukan sekadar manusia menaati dari tindakan luar, tetapi menaati dengan sukacita. Ketaatan dengan sukacita ini lahir karena manusia menyadari bahwa Kristus sudah menebus dosa mereka. ${ }^{74}$ "True convertion is proved by the constant tenor of the life; because we are redeemed, to this end that we should serve God, our Deliverer, in holiness and righteousness all the days of our life". ${ }^{75}$ Jika manusia mempercayakan dirinya dipimpin oleh hukum moral, manusia tidak akan terhilang. Calvin menyatakan, umat Tuhan yang mengerti hukum moral adalah orang yang belajar, orang yang merendahkan diri di hadapan Tuhan dan menyerahkan diri dipimpin oleh Roh Kudus. ${ }^{76}$

Berada pada posisi siap diajar, didukung oleh gereja yang siap memberikan pengajaran yang benar dan aplikatif sebagaimana yang

\footnotetext{
Calvin, Commentary upon The Book of Psalms, 479.

Calvin, Commentaries on the Epistle to Romans, 219.

Calvin, Calvin's Harmony of the Four Last Book of Pentateuch, 289.

Calvin, Commentary upon The Book of Psalms, 318.

Calvin, Calvin's Harmony of the Four Last Book of Pentateuch, 287.

Calvin, Commentary upon The Book of Psalms, 320.
} 
dilakukan Calvin pada jamannya. Thomas H. L Parker mengukuhkan hal ini, ia menyatakan bahwa Calvin memaparkan hukum moral dalam konteks pendengar sehingga mereka mengerti dan mengaplikasikannya.7 ${ }^{77}$ Selain melalui pengajaran, Calvin juga mendirikan konsistori yang menangani masalah imoralitas kesucian hidup, atau seks di Jenewa. ${ }^{78}$

Pada jaman sekarang, agar pengajaran hukum moral aplikatif dalam konteks pergumulan homoseksual maka pengajaran hukum moral dapat diberikan dalam bentuk tindakan kuratif dan preventif. Tindakan kuratif dengan cara gereja menyediakan pelayanan konseling. Dalam wadah konseling ini, gereja memberikan pengajaran dan perhatian kepada mereka sebagai satu tubuh Kristus yang sudah Tuhan selamatkan dan mendorong mereka menaati kehendak Tuhan. ${ }^{79}$ Gereja juga menerima orang-orang homoseksual yang sudah bertobat, tidak mengucilkan mereka. Karena semua manusia diselamatkan hanya karena anugerah.

Untuk tindakan pencegahan, gereja mempromosikan pernikahan heteroseksual, yang dirancang oleh Tuhan adalah pernikahan yang terbaik. ${ }^{80}$ "Our ethics of Character has to ask how the church might instead model and foster upbuilding, non genital, same gender friendships, and how we could positively assist young people in discovering their sexual identity according to God's creating design". .1

\footnotetext{
77 Thomas H. L. Parker, “Calvin's New Testament Commentaries" (London: SCM,1971), 80 dalam Douglas Kelly, “Varied Themes In Calvin's 2 Samuel Sermons and the Development of His Thought", dalam Wilhem H. Neuser, Calvinus Sincerioris Religionis Vindex, diedit oleh Wilhem H. Neuser dan Brian G. Armstrong (Missouri: Sixteenth Century Journal Publishers, 1997), 212.

78 John Witte Jr. dan Robert M. Kingdon, Sex, Marriage, And Family in John Calvin's Geneva. (Cambridge: William B. Eerdmans Publishing Company, 2005), 77.

79 Dawn, 109.

80 Derrick Sherwin Barley, "Homoseksuality: A Symbol of Confusion", dalam Stanley J. Grenz. Sexual Ethics An Evangelical Perspective, (Kentucky: Westminster John Knox Press, 1997), 245.

81 Dawn, 107.
} 